\title{
Investors' distraction and strategic repricing decisions
}

\author{
Marco Navone ${ }^{\mathrm{a}, *}$ \\ ${ }^{a}$ Finance Discipline Group, UTS Business School, PO Box 123, Broadway NSW 2007, Australia
}

This Version: November $22^{\text {nd }}, 2011$

\begin{abstract}
In this paper I analyze investors' reactions to changes in the expense ratios of equity mutual funds. I show that investment flows' response to fees cannot be fully explained by looking at investors' performance sensitivity. While performance sensitivity monotonically increases with past performance, price sensitivity does not: investors who buy top past performers seem to be "distracted" by the fund's previous return and pay relatively little attention to the expense ratios. Moreover price sensitivity increases with fund visibility while performance sensitivity decreases, and while looking at data from 1986 to 2006 no discernible trend can be observed in the average performance sensitivity, price sensitivity strongly increases due to the dramatic increase in the availability of mutual funds' information for retail investors. Finally I show that investment companies strategically time their repricing decisions in order to exploit time variations in price and performance sensitivities, and that fund governance quality affects the degree to which investment companies engage in this opportunistic behavior.
\end{abstract}

JEL classification: G11; G23

Keywords: Mutual funds; Expense ratios; Price sensitivity

* Corresponding author. Tel: +61 29514 7736; fax: +61 295147711.

E-mail address: marco.navone@uts.edu.au (M. Navone) 


\section{Introduction}

Pricing in the mutual fund industry is rapidly emerging as a new puzzle in finance as more and more papers document a negative relationship between the quality of the fund management services provided (measured by the gross performance of the fund) and the price charged to investors (measured by the expense ratio). According to Christoffersen and Musto (2002), this evidence can easily be rationalized if one assumes that performance-sensitive investors tend to avoid poorly managed funds and invest in top performers. This generates a situation in which high-quality funds are populated by performance-sensitive investors while shares of low-quality funds are mainly held by subjects with low sensitivity to fund performance. The negative correlation between quality and price would thus arise from a rational pricing policy whereby performance-insensitive investors are charged higher prices than performance-sensitive ones. This explanation is also supported by GilBazo and Ruiz-Verdú (2009) for a larger sample of equity mutual funds1.

In both these contributions prices are seen as an optimal response to performance sensitivity, but an increasing body of literature shows that investors do not consider expenses simply as a negative component of net returns: experimental analysis of the investment process of individual investors as well as surveys on the elements considered at the moment of choosing a fund show that investors evaluate past performance and expenses separately when selecting an investment option. The evidence shows that the relative importance of the two pieces of information varies across the population of mutual fund investors (Capon et al., 1996) and is affected by demographics such as gender, income and education (Wilcox, 2003; Choi et al., 2010). Moreover, if search costs and information availability affect how investors react to past performance (Huang et al., 2007), an even stronger ef-

\footnotetext{
${ }^{1}$ On a similar sample Iannotta and Navone (2011) document a relevant level of fee dispersion not justified by observable heterogeneity among funds.
} 
fect has to be expected on their sensitivity to expenses, as this information is much harder to come by than past performance.

Unlike previous research, in this paper I analyze pricing decisions as a strategic response to investor sensitivity to expenses measured in conjunction with their sensitivity to past performance. I show that the two sensitivities differ both in the time series and in the cross-section. Specifically I point out three major differences: first of all, while performance sensitivity monotonically increases with prior performance, price sensitivity does not: it increases with past performance in the lower part of the ranking but decreases in the upper portion. For funds in the lower part of the category ranking, as investment flows become more sensitive to past performance they also become more sensitive to expense ratios (coherently with the underlying assumption of previous research), but as one moves into the upper portion of the performance ranking an increase in performance sensitivity is met by a decrease in fund flows' sensitivity to expenses. I label this evidence the "distraction effect": when a fund performs well investors do not care about expenses, as if they are "distracted" by the perceived managerial ability and the relative prospective returns.

I also show that performance and price sensitivity are affected differently by search costs and fund visibility: investment flows in and out of funds with lower search costs (larger and older funds and funds managed by larger investment companies ${ }^{2}$ ) are, cœteris paribus, less sensitive to past performance and more sensitive to expenses. This difference can be explained by considering that while investors can find data on the past performance of most mutual funds in any major newspaper, until recently information on expense ratios could only be found in fund prospectuses and annual reports. Investors seem to rely more heavily on "cheap-to-find" information when search costs are higher, while "hard-to-come-by" data heavily influence investment decisions only for highly visible funds.

\footnotetext{
${ }^{2}$ These are the proxies for search costs used by Huang et al. (2007). 
Finally flow sensitivities to past performance and expenses also differ in terms of temporal evolution: while the former do not exhibit any defined temporal trend, the latter steadily increase in my sample period (1986-2006), showing a growing relevance of expenses in the investment decision process, probably fueled by the increased amount of processed data on expense ratios made available to the general public by specialized information providers.

In the second part of the paper I analyze expense ratio changes (repricing decisions) as a response to changes in the sensitivity of investors to fund performance and expenses and I show that investment companies strategically time their repricing decisions in order to optimize the effect on investment flows: a decrease in the expected sensitivity of investment flows to performance and expenses is associated with a higher subsequent change in the fund expense ratio even after controlling for changes in fund size that could yield a diminished effect of fixed management costs. The opportunistic nature of this repricing behavior is confirmed by the fact that it appears to be stronger in funds with lower-quality governance as measured by the Morningstar Stewardship Grades.

The rest of the paper is organized as follows: Section 2 analyzes the main results in the literature regarding the determinants of investment decisions; Section 3 presents the database and some descriptive statistics; Section 4 deals with the quantification of performance and price sensitivity; Section 5 analyzes repricing decisions; and Section 6 concludes.

\section{The determinants of investment decisions}

Analyzing the puzzling evidence of price dispersion in the context of money market funds, Christoffersen and Musto (2002) conclude that investors who do not steer clear of a poorly performing fund are clearly insensitive to mutual fund performance and thus are charged a higher expense ratio because "from its investors' point of view, a fund's fee is simply a direct reduction of performance, so performance insensitivity implies price insensitivity, which, holding all else constant, implies a 
higher optimal price.” Gil-Bazo and Ruiz-Verdú (2009) employ the same consideration in trying to justify the negative correlation between gross performance and expense ratios in a large sample of equity US mutual funds when they say that "funds with lower expected performance optimally set higher fees and target performance-insensitive investors."

The idea that performance sensitivity implies price sensitivity is theoretically compelling: the prevailing paradigm of portfolio theory is based on the assumption that investors maximize a utility function based on the moments of expected net returns distribution and thus higher management fees would affect the utility (and the subsequent optimal portfolio composition) via a reduction in the mean expected return.

When we abandon the necessary simplifications of this model and take a deeper look at the investment decision process we observe that investors evaluate prospective investments along multiple dimensions. Capon et al. (1996) surveyed a sample of 3,386 investors, asking them to rank nine selection criteria in order of their relevance to guiding the choice of mutual funds. They later clustered the results in order to form three groups of homogenous investors. The nine selection criteria range from the investment performance track record and expenses to the quality of customer support, the presence of additional services (brokerage, checking, etc.) and the community service track record of the investment company. Of the three investor groups resulting from the clustering of the rankings one clearly emerges as more interested in the non-economic component of the service ${ }^{3}$ (low relevance of the performance track record and fees and high relevance of the service-related variables) while the other two focus more on the financial aspects of the service (performance track record, fund manager reputation, number of funds managed, etc.). The main difference between these two groups of financially motivated investors is the relevance of expenses; some investors, in fact,

\footnotetext{
${ }^{3}$ The existence of such a group indirectly confirms the intuition of Hortaçsu and Syverson (2004) and Bergstresser et al. (2009) that non-portfolio-related services could play a significant role in the pricing of portfolio management services.
} 
despite assigning high relevance to the performance track record of the fund, do not consider fund expenses as important in the investment choice, thus apparently contradicting the equivalence between price and performance sensitivity.

Wilcox (2003) follows a similar line of research in an experimental setting: 50 consumers were presented with profiles of different equity mutual funds and asked to select their most preferred fund. Each participant was presented with 20 choice tasks, leading to a sample of 1,000 investment decisions used to estimate the relevance of the different elements contained in the fund profiles (fund loads and management fee, short- and long-term past performance and fund risk). The study reaches two main conclusions: the first one is that "investors pay less attention to fees than to past performance metrics" and the second is that the relative importance of management fees with respect to past performance is heavily influenced by the demographic profile of the investor, with wealthy, highly educated and highly finance-savvy investors placing more importance on past performance and less on expenses.

Finally Choi et al. (2010) asked investors belonging to three different groups (MBA students from Wharton, college students from Harvard and staff employees from Harvard) to allocate a hypothetical $\$ 10,000$ across four real S\&P 500 index funds (after receiving copies of the fund $\mathrm{es}^{4}$ ). The authors confirm that not only does the relative importance of expenses and past returns in the decision process vary across the three populations, but that within each of them the demographic variables significantly influence the relevance of the two factors, leading to the formation of portfolios with different characteristics in terms of average cost and past track record.

The fact that investors do not consider expenses simply as a negative component of net performance can also be inferred by the results of Alexander et al. (1998). In a survey of more than 2,000 inves-

\footnotetext{
${ }^{4}$ The different control groups were also provided with additional information on fees and past performance. 
tors the authors asked if a fund with higher than average expenses had to be expected to deliver a performance above, about or below the average in the future. The bulk of investors (64.4\%) expected this fund to deliver a performance close to the average of the industry, $19.9 \%$ expected a performance higher than average (implying a positive relationship between performance and fees) and only $15.7 \%$ answered that a fund with higher fees should deliver a lower than average performance.

While the previous contributions clearly show that investors do not consider expenses simply as a negative component of net performance, they do not address the issue of the rationality of this behavior. Bailey et al. (2010) overcome this shortcoming by analyzing the portfolio choices of over 32,000 retail investors who bought mutual fund shares between 1991 and 1996 and show that wellknown behavioral characteristics such as overconfidence and narrow framing are linked to higher than average performance sensitivity and, at the same time, to a higher probability of choosing expensive funds.

Judging the rationality of portfolio choice criteria is beyond the scope of this contribution. The fact that fees and performance are considered separately may be a signal of naïve investment behavior or of the fact that they both affect the expectation of future performances in a non-trivial way. What is relevant here is that additional insights can be gained by modeling the two sensitivities separately.

\section{Database}

I use data from the Center for Research in Security Prices (CRSP) Survivorship Bias Free Mutual Fund Database, from which I obtain information about funds' net asset values, returns and characteristics. Data are collected from 1986 to 2006 on all non-industry-specific US domestic equity funds with assets under management, at the beginning of the year, above the twenty-fifth percentile 
of the industry distribution. ${ }^{5}$ Since CRSP does not provide consistent fund investment objectives and fund family names for the years prior to 1992, following Huang et al. (2007) I classify funds into different categories and identify their family affiliation based upon the CDA-Spectrum mutual fund data from Thomson Financial, Inc. In order to obtain a sample of rather homogenous investment products I only consider funds that follow three investment objectives: aggressive growth, growth, and growth and income.

Index and institutional funds are excluded from the sample because of the focus on flows into actively managed retail funds. Since CRSP does not identify index and institutional funds prior to 1999, I follow, prior to this date, the identification methodology proposed by Gil-Bazo and RuizVerdú (2009) based on text recognition in the name of the fund. ${ }^{6}$ The number of funds in the sample grows from 342 in 1986 to 2,234 in 2006. As can be noted from Table 1, the sample size is smaller than what is reported in comparable studies, for example Huang et al. (2007). The difference is due to our minimum size requirement; removing this constraint would bring the sample size and other characteristics perfectly in line. Table 2 reports the asset-weighted mean coefficients of the FamaFrench 3-factor and Fama-French-Carhart 4-factor models estimated over 5-year non-overlapping periods. The numbers confirm the representativeness of the sample.

\section{[Insert Table 1 and Table 2 about here]}

\footnotetext{
${ }^{5}$ This variable cut-off point is preferable to the standard practice in the literature of droping all the observations with an AUM below $\mathrm{X} \mathrm{m} \$$, as this number is usually not inflation-adjusted. In terms of the number of observations dropped, the variable cut-off is similar to a $15 \mathrm{~m} \$$ fixed minimum requirement. As a robustness check all the analyses have been replicated using a $10 \mathrm{~m} \$$ and $15 \mathrm{~m} \$$ fixed minimum AUM requirement and all the results hold.

${ }^{6}$ A fund is considered an index fund if the name contains any of the following strings: "Index," "Idx," "Ix," "Indx," "NASDAQ," "Nasdaq," "Dow," "Mkt," "S\&P 500" or "BARRA." In the same way a fund is considered institutional if the name contains "Inst" or "inst" or if it belongs to share classes "Y" or "I."
} 
For the period considered in this study CRSP reports some unreasonably high values for expense ratios (for example, there are 10 observations with values above $30 \%$ ). In order to avoid bias in our estimates due to these outliers I winsorize the expense ratio distribution at the $1 \%$ level, leaving a maximum value of $3.02 \%$.

Following a common practice in mutual fund flows research I also winsorize the net flows at the $5 \%$ level in order to avoid extreme values generated by errors associated with mutual fund mergers and splits in the CRSP mutual fund database (for a detailed description of this problem see Elton et al., 2001).

Since I focus my research on expense ratios and their dynamics, the definition of the observation period is a key element in the database-building process: mutual funds report expense ratios on the base of a fiscal year that seldom coincides with the calendar year. In the database all the expenserelated variables are defined over the fiscal year and the performance-related variables are calculated accordingly: the 12-month rank of the fund, for example, is the position of the fund in its category ranking calculated over the fiscal year of the fund.

\section{Price and performance sensitivity}

In order to estimate the price and performance sensitivity I follow the intuition of Gil-Bazo and Ruiz-Verdú (2009) and model fund net flows as a function of past performance, expenses and other control variables that capture stylized facts reported in the previous literature.

Net flows are defined as the percentage growth of total net assets (TNA) adjusted for the fund return net of expenses $\left(r_{i t}\right)$ :

$$
\text { Flow }_{i t}=\frac{T N A_{i t}-T N A_{i t-1}\left(1+r_{i t}\right)}{T N A_{i t-1}}
$$


Flows are calculated on a monthly basis and aggregated over the fiscal year in order to minimize the approximation errors due to the timing of investment decisions.

As the performance measure I consider the fund's fractional rank in the previous fiscal year (Perf). This represents its percentile performance relative to other funds (on the basis of a fund's one-year raw return) with the same investment objective in the same period, and ranges from 0 to 1 . This measure captures the tournament nature of the mutual fund industry (Brown et al., 1996) and has been proven to be highly relevant in terms of its ability to capture investors' behavior. ${ }^{7}$ A tricky methodological question is whether this measure should be calculated gross or net of the expense ratio. On the one side, in fact, investors acquire information on ranking from news sources that usually report net performances; on the other hand calculating a gross performance measure would have the advantage of avoiding a double representation of expenses in our model. Albeit relevant from the theoretical point of view, this problem is of little practical importance in this experiment: the level of the cross-sectional volatility of equity funds' annual return is such that the correlation between gross and net ranking measures is above 0.98 . As a robustness check I run the experiment using both measures and the results are indistinguishable. For the sake of comparability with previous research I will report the results using net ranking measures. As an additional robustness check all the analyses are replicated using as the performance measure the Fama-French three-factor alpha and the Fama-French-Carhart four-factor alpha calculated according to the two-step procedure introduced by Carhart (1997). All the major results are robust to these alternative specifications. ${ }^{8}$

In order to capture the non-linearity of the flow-performance relationship (Ippolito, 1992) I follow two different methodologies: in the first I introduce a quadratic performance term $\left(\right.$ Perf $\left.^{2}\right)$ while in the second I interact the performance variable with two dummy variables (High and Mid) for funds

\footnotetext{
${ }^{7}$ See, for example, Sirri and Tufano (1998), Huang et al. (2007), Kempf and Ruenzi (2008) and Kempf et al. (2009).

${ }^{8}$ The results are available from the author upon request. 
in the top and the middle third of the performance distribution. I introduce the two models in order to address the robustness of the main result to the functional specification of the flow-performance relationship.

Expenses are represented by two variables, the total expense ratio (Exp) and a dummy variable for load funds (Load). The results of Barber et al. (2005) suggest considering the two cost components separately as they may affect investors' behavior in different ways. Moreover Bergstresser et al. (2009) document relevant differences between load funds and no-load funds and Navone and Pagani (2009) show how loads can affect the flow-performance relationship. In this paper I investigate the dynamics of the expense ratios so the analysis will focus on these variables while loads will be used as controls. In order to capture the interaction between the sensitivity of fund flows to prices and the performance of the fund I introduce interaction terms between the expense ratio and the performance measures (Perf and Perf ${ }^{2}$ in the quadratic model and Mid and High in the dummy variable model).

A key element in the potential explanation for the response of investors to prices and performance is the different availability of these two pieces of information. Newspapers currently report the past performance of mutual funds but do not report the past expense ratios. In order to acquire this information investors have to analyze fund prospectuses and reports or, in recent years, look at online or in print specialized information providers. As Huang et al. (2007) demonstrate, search costs can influence investment behavior significantly: if investors have to acquire information prior to the investment in a fund the reaction of investment flows to past performance will be a function of the cost of acquiring this information. In order to analyze how search costs influence the sensitivity of mutual fund flows to performance and price I consider their interaction with four possible measures of fund visibility: (the natural logarithm of) fund asset under management (Size) and age (Age) at 
the beginning of the year, (the natural logarithm of) size of the fund complex in terms of total AUM (ICSize) and the number of fund categories in which the investment company is present (ICCat). ${ }^{9}$

Both models also include, as controls, dummy variables for load funds (Load) and for funds that belong to "star" families (Star), ${ }^{10}$ the fund standard deviation $(S t d)$, the asset-weighted net flow into funds with the same investment objective in time $t$ (IOFlow) and (the natural logarithm of) the fund size (Size) and age (Age) and fund complex size (ICSize), as well as the number of investment categories in which the fund complex is present (ICCat). Since different fund share classes can cater to investors with different characteristics (as noted, for example, by O’Neal, 1999 and Nanda et al., 2009), I also control for share classes with three dummy variables for A, B and C share classes. ${ }^{11}$

Ivkovic and Weisbenner (2009) show that unrealized capital gains (proxied by the difference between the current value of the NAV and the purchase price of the mutual fund shares) affect mutual fund flows as investors may be restrained from selling shares for tax-related reasons. The authors build their measure at the level of individual investors. This methodology unfortunately is not replicable in my dataset based on aggregated investment flows. In order to capture the same idea I introduce into the flow-performance relationship a measure, CGAIN, defined as the ratio between the current value of the NAV of the fund and the maximum value of the NAV in the last 60 months (or in the last 24 in an alternative specification). A value close to 1 means that the fund is trading close to its maximum historical price and thus is likely to be owned by investors with significant unrealized capital gains.

\footnotetext{
${ }^{9}$ Although in my paper I only consider funds from three CDA-Spectrum categories, this last variable is calculated considering all the available categories.

${ }^{10}$ Consistent with Nanda et al. (2004), I define a "star" as a fund that ranks in the top 5\% of its own category. The variable STAR is a dummy set equal to one for all the funds belonging to a complex that has at least one "star."

${ }^{11}$ Share classes are assigned on the base of the name. For example a share class is labeled "A" if the name contains: "A Shares," "A" or "Class A." As a robustness check I also test a different specification with an alternative dummy variable for primary share classes (the share class with the higher asset under management) without any significant difference in the results.
} 
Finally all the models will also consider fixed effects at the investment objective and fund levels.

Several recent contributions have also highlighted the "stickiness" of mutual fund flows, suggesting the introduction of the lagged value of flows $\left(F l o w_{t-1}\right)$ as an explanatory variable in the model. ${ }^{12}$ The introduction of lagged flows on the right-hand side of our equation is non-trivial due to the limited time variation of many of the explanatory variables traditionally used to explain mutual fund flows (for example mutual fund size and age). There is also a serious econometric problem due to the panel nature of our sample and the relationship between lagged flows and fund fixed effects. In order to address this issue and test the robustness of the results I estimate my models both without and with lagged flows. In the latter case the models are estimated using the Arellano and Bond (1991) dynamic panel robust estimation specifically designed to address this issue. ${ }^{13}$

Both the dependent variable (investment flows) and many of the independent variables (for example fund sizes) may vary significantly across time periods and fund types. I address this issue by defining all the continuous variables as deviation from the mean of the year/fund category.

The quadratic model can be represented as follows:

$$
\begin{aligned}
\text { Flow }_{i t}= & a+b_{0} \text { Flow }_{i t-1}+b_{1} \operatorname{Perf}_{i t-1}+b_{2} \operatorname{Perf}_{i t-1}^{2}+b_{3} \operatorname{Exp}_{i t-1}+b_{4} \operatorname{Perf}_{i t-1} \times \operatorname{Exp}_{i t-1}+b_{5} \operatorname{Perf}_{i t-1}^{2} \times \operatorname{Exp}_{i t-1}+ \\
& +c_{1} \operatorname{Perf}_{i t-1} \times \operatorname{Vis}_{i t-1}+c_{2} \operatorname{Exp}_{i t-1} \times \operatorname{Vis}_{i t-1}+\gamma \text { Controls }_{i t-1}+\varepsilon_{i t-1}
\end{aligned}
$$

where Vis $_{i t-1}$ is the proxy for fund visibility used in the specific regression and Controls $s_{i t-1}$ is the matrix of the control variables that include the fixed effects.

\footnotetext{
${ }^{12}$ To the best of my knowledge the issue of autocorrelation of flows first appeared in the works of Zeckhauser et al. (1991) and Patel et al. (1994). More recently the issue has been addressed by Fant and O'Neal (2000) and Cashman et al. (2007). Lagged flows explanatory variables are also used by Gil-Bazo and Ruiz-Verdú (2009).

${ }^{13}$ The results for the model estimated without lagged flows are available from the author upon request. 
Following Gil-Bazo and Ruiz-Verdú (2009) I calculate performance and price sensitivity as the derivative of investment flows with respect to past performance and past expense ratio:

$$
\begin{aligned}
& \text { PERF_Sens }{ }_{i t}=\frac{\partial E_{t-1}\left(\text { Flow }_{t}\right)}{\partial \operatorname{Perf}_{i t-1}}=b_{1}+2 b_{2} \operatorname{Perf}_{i t-1}+b_{4} \operatorname{Exp}_{i t-1}+2 b_{5} \text { Perf }_{i t-1} \times \operatorname{Exp}_{i t-1}+c_{1} \operatorname{Vis}_{i t-1} \\
& \text { PRICE_Sens }{ }_{i t}=\frac{\partial E_{t-1}\left(\text { Flow }_{t}\right)}{\partial \operatorname{Exp}_{i t-1}}=b_{3}+b_{4} \operatorname{Perf}_{i t-1}+b_{5} \operatorname{Perf}_{i t-1}^{2}+c_{2} \operatorname{Vis}_{i t-1}
\end{aligned}
$$

In the same way we can represent the dummy variable model as follows:

$$
\begin{aligned}
& \text { Flow }_{i t}=a+b_{0} \text { Flow }_{i t-1}+b_{1} \text { Perf }_{i t-1}+b_{2} \text { Perf }_{i t-1} \times M i d+b_{3} \operatorname{Perf}_{i t-1} \times H i g h+b_{4} \operatorname{Exp}_{i t-1}+b_{5} \operatorname{Exp}_{i t-1} \times M i d+b_{6} \operatorname{Exp}_{i t-1} \times H i g h+ \\
& +c_{1} \text { Perf }_{i t-1} \times V i s_{i t-1}+c_{2} \operatorname{Exp}_{i t-1} \times V i s_{i t-1}+c_{3} V i s_{i t-1} \times M i d+c_{4} V i s_{i t-1} \times H i g h+ \\
& +d_{1} \times \text { Mid }+d_{2} \times \text { High }+\gamma \text { Controls }_{i t-1}+\varepsilon_{i t-1}
\end{aligned}
$$

The sensitivities can be calculated as:

$$
\begin{aligned}
& P E R F_{-} \text {Sens }_{i t}=\frac{\partial E_{t-1}\left(\text { Flow }_{t}\right)}{\partial \operatorname{Perf}_{i t-1}}=b_{1}+b_{2} \text { Mid }+b_{3} \text { High }+c_{1} V i s_{i t-1} \\
& \text { PRICE_Sens } s_{i t}=\frac{\partial E_{t-1}\left(\text { Flow }_{t}\right)}{\partial \operatorname{Exp}_{i t-1}}=b_{4}+b_{5} \text { Mid }+b_{6} H i g h+c_{2} \text { Vis }_{i t-1}
\end{aligned}
$$

The sensitivities are estimated on a version of the model in which all the four visibility proxies are employed. Moreover, in order to allow more flexibility in the time variation of the sensitivities, I also include time fixed effects and their interaction with performance, expenses and the visibility 
proxies. ${ }^{14}$ It is important to note that PRICE_Sens $s_{i t}$ is based on fund information at $t-1$ and thus can be seen as the expected value at $t-1$ of the sensitivity of flows to expense ratios at time $t$.

\section{[Insert Table 3 and Table 4 about here]}

Table 3 and Table 4 report the results for the quadratic model and the dummy variables model, respectively. ${ }^{15}$ The two models yield very similar results: as far as the flow-performance relationship is concerned the data support the evidence, in line with the existing literature, of a positive and asymmetric relationship (positive and significant coefficients for $\operatorname{Perf}^{2}$ in the quadratic model and both Perf $x$ Med and Perf $x$ High in the dummy model). As expected the relationship between expense ratios and flows is negative and highly significant. Interestingly the data show that this relationship is influenced by the past performance of the fund: specifically for top-performing funds the net investment flows are less negatively influenced by higher expense ratios. This evidence can be derived from the positive coefficients of the interactions between expense ratios and performance in the quadratic model (Perf $x \operatorname{Exp}$ and $\left.\operatorname{Perf}^{2} x \operatorname{Exp}\right)$ and from the positive coefficients of the interaction between expense ratios and the dummy variables for top-performing funds in the dummy variables model (Exp $x$ Mid and Exp $x$ High). Overall investors seem to punish expensive funds by investing less but this punishment is less severe for top-performing funds. I call this phenomenon the "distraction effect": investors are distracted by the recent exploits of the fund manager and pay less attention to the costs of the service provided. One could argue that a possible alternative interpreta-

\footnotetext{
${ }^{14}$ An alternative possibility would be to introduce explicitly time-related factors that should drive investor sensitivities to performance and prices. For example Kim (2010) shows that market volatility and fund returns' cross-sectional volatility affect the informativeness of fund performance and thus performance sensitivity. Although an alternative specification of the model with these two volatility-related conditioning variables yields similar results, the time fixed effect approach is more flexible as it can accommodate a variety of sources of time variation.
} 
tion of the result is simply that investors do not complain about high management fees when they think that their money is not being wasted but is functional in producing superior performance. The determination of the degree of consciousness in the investors' behavior is clearly beyond the scope of this study; what is relevant is that high fees are less harmful, in terms of lower investment flows, for funds with a good track record.

A comparative static exercise can help to gauge the material relevance of the distraction effect: making reference to the coefficients of model (a.4) in Table 3 we can estimate that the expected net percentage investment flow for a top-performing fund (the top 10\% of the performance ranking) would be $27.18 \%$ and $15.54 \%$ for the median fund. The marginal effect of an increase in the expense ratio from the sample mean to the seventy-fifth percentile (from $1.36 \%$ to $1.87 \%$ ) would be very different for the two funds: the median fund would lose almost two-thirds of the expected investment flow (down $9.33 \%$ to $6.22 \%$ ) while the effect would be lower for the top-performing fund both in relative and in absolute terms (a 5.54\% reduction, equivalent to one-fifth of the original flow). ${ }^{16}$ One could argue that the marginal effect overstates the real phenomenon because it does not take into account the negative effect of the increase in the expense ratio on the performance of the fund and the fact that the top-performing fund has higher sensitivity of flows to performance. While this is clearly true the reader should also consider that the performance measure considered in the model (the fractional ranking) is extremely robust to small variations in the fund return: the average difference between the ninetieth and the eighty-ninth percentile of annual return distributions is 103 basis points so an increase in the expense ratio of 51 bps would hardly change the position of the fund in the performance ranking. We can thus conclude that the distraction effect is em-

\footnotetext{
${ }^{15}$ For the sake of simplicity coefficients of the control variables are omitted but are available from the author upon request.

${ }^{16}$ The repetition of this exercise with the coefficients of the dummy model in Table would produce roughly the same results.
} 
pirically relevant: top-performing funds can significantly increase their expense ratio without being harshly punished by the investors.

A second interesting result concerns the effect of mutual fund visibility on the sensitivity of mutual fund flows to performance and fees. If acquiring information on mutual fund expense ratios is more expensive than acquiring information on past performance we should observe a different effect of visibility on the two sensitivity measures. Again the coefficients in Table 3 and Table 4 support the idea that fund visibility increases investors' price sensitivity: since it is cheaper to acquire information on the funds investors' decisions will be more heavily based on it. The interaction between the expense ratio and the three proxies for fund visibility is always negative and significant regardless of the model. A negative coefficient means that the relationship between flows and fees becomes "more negative," hence we can say that the sensitivity increases. Again some comparative statics can help to gauge the materiality of this effect: an increase in the expense ratio from the sample mean to the seventy-fifth percentile generates a reduction in the investment flow of $9.33 \%$ for the median fund in the previous example. This reduction would be only $5.13 \%$ for a "low visibility fund," defined as a fund with age, size and investment company size and span at the twentyfifth percentile of their distributions, but would grow to $14.33 \%$ for a fund with "high visibility" (size, age and investment company size and span at the seventy-fifth percentile).

Admittedly fund size and age and investment company size (and span) are only imperfect proxies for fund visibility, but it is interesting to note that while older and larger funds (and funds managed by larger investment companies) experience a higher sensitivity of fund flows to expense ratios, the same is not true for their sensitivity to past performance: an increase in performance from the median to the seventy-fifth percentile of the performance distribution would generate an increase of $5.47 \%$ in flows for a high-visibility fund and $6.98 \%$ for a low-visibility fund. The opposite effect of fund visibility on price and performance sensitivities can be rationalized starting from the idea that it is cheaper to acquire information on past performance than on expense ratios, so when the search 17 
costs are high investors rely more heavily on this "cheap" piece of information. When the search costs are lower investors base their decisions on a larger information set, lowering the sensitivity of flows to past performance. Although this interpretation could be biased by the fact that all the fund characteristics that are likely to capture some aspects of information availability are also going to influence either the economics of the fund management company or the performance of the fund, the fact that all four proxy variables yield coherent coefficients is somewhat reassuring.

The relevance of fund visibility to the determination of price and performance sensitivity raises another interesting question: the information availability on mutual funds changed dramatically over the sample period covered in this study. In recent years specialized information providers have allowed investors easily to confront and rank mutual funds not only on past performance but also on expenses and other features. Has this global reduction in search costs affected the sensitivity of mutual fund flows to past performance and expense ratios? In order to answer this question I add to the previous regression model interaction terms between time fixed effect on one side and performance, fee and visibility variables on the other. ${ }^{17}$

Figure 1 shows the evolution in time of the performance and price sensitivities for the average fund. It is easy to see that the two sensitivities show significantly different time patterns: while there is no visible trend for the sensitivity of investment flows to past performance, apart from a spike in the 1999-2000 period, the price sensitivity has increased steadily during the 20 years considered in this study with a significant acceleration in the last decade. Of course this time frame is also coincident with a dramatic increase in the availability of low-cost investment alternatives such as exchange traded funds (which, according to the Investment Company Institute rose from 66 b\$ in 2000 to 581 b\$ in 2007). The contemporary presence of greater availability of information on fund expenses and

\footnotetext{
${ }^{17}$ This regression is estimated both for the quadratic and for the dummy models. The estimated coefficients are available from the author upon request.
} 
readily available low-cost alternatives helped to put fund costs on the front stage of the fund selection process of retail investors.

\section{[Insert Figure 1 about here]}

The fact that investors have been paying increasing attention to fees is coherent with the previous interpretation of the relevance of visibility and information availability in general. The fact that performance sensitivity does not exhibit a similar trend confirms the opportunity to model the two sensitivities separately. Given the fact that information on funds' past performance is cheap and has always been widely available, the sensitivity of investment flows to past performance has not changed dramatically in the sample period, with the notable exception of the so-called "Internet bubble" period, during which investors had evidently been concentrating investment flows on topperforming funds. ${ }^{18}$

In conclusion this part of the analysis shows that investors allocate flows looking both at past performance and at expense ratios but the sensitivity to these two variables is significantly different: specifically, while performance sensitivity monotonically increases with past performance (as noted in the previous literature), price sensitivity does not: investors seem to suffer a "distraction effect," paying less attention to expense ratios for top-performing mutual funds. Moreover price sensitivity is positively affected by fund visibility and has been growing steadily during the last 20 years as information on mutual funds has become more widely available.

\footnotetext{
${ }^{18}$ The reader should remember that both the flow and the performance measure are normalized within fiscal years and investment objective so this result cannot possibly be generated by scale effects in fund performance or investment flows.
} 


\section{Price sensitivity and repricing decisions}

Previous research on expense ratios has mainly focused on the level of fund expenses, while relatively little attention has been paid to the time variation of this quantity at the fund level. The dynamics of these changes is intriguing: practitioners usually justify repricing decisions considering that investment companies have fixed costs, thus when the assets under management decrease (because the stock market goes down, for example) they "are forced" to increase the expense ratios. This explanation rests on the mechanics of economies of scale and on the fact that advisory agreements usually stipulate that the remuneration of the fund advisor, as a percentage of the asset under management, is negatively correlated with fund size, but it seems unlikely that fee changes are only motivated by fund performance and size dynamics: fee changes show a coefficient of variation 7 time larger than that of fund annual returns and almost 4 times larger than that of assets under management percentage changes. Abundant anecdotal evidence could also be provided to show the insufficiency of the above-mentioned explanation: for example in 1996 the Prudential Utility Fund produced a performance of $22 \%$, ending in the top $20 \%$ of its category ranking. During the fiscal year the assets under management grew from $\$ 1.7$ billion to $\$ 2$ billion and, coherently with the fixed-cost explanation, in the next fiscal year the fund reduced the expense ratio from 88 to 57 bps (a 35\% decrease). In 1997 the fund repeated its good performance, yielding a total return of 27.7\% (top 25\% of the ranking), and experienced an increase in the asset under management from $\$ 2$ billion to $\$ 2.58$ billion. Surprisingly, the following year, the investment company decided to increase the expense ratio from 57 to $78 \mathrm{bps}$, with a percentage increase close to $37 \%$.

Table 5 reports summary statistics for expense ratio changes from 1986 to 2006. Although in the whole sample there is roughly the same frequency of increases and decreases we also observe a significant time variation with years when more than two-thirds of the funds increased the expense ratios and years when the opposite is true. The spread between the tenth and the ninetieth percentile of 
the distribution of percentage changes in the expense ratios as well as the cross-sectional standard deviation also testify to the existence of a significant cross-sectional variation: in the entire sample the mean and median percentage changes are close to zero but with a standard deviation of $8.64 \%$.

\section{[Insert Table 5 about here]}

In the previous section I showed that the sensitivity of investment flows to past performance and prices presents significant cross-section and time-series variation. In this part I test whether investment companies strategically time their repricing decisions in order to exploit these variations.

In order to test for this assumption I regress changes in expense ratios over changes in price sensitivity, controlling for changes in performance sensitivity and other fund-related control variables that should capture the mechanical effects related to changes in economies of scale. Specifically Table 6 reports the results of five panel regression models in which the dependent variable is the difference between the expense ratios charged by each mutual fund in years $t$ and $t-1$.

\section{[Insert Table 6 about here]}

The first three models only consider changes in the expected price and performance sensitivities of fund shareholders between years $t$ and $t-1, \triangle P R I C E \_S e n s$ and $\triangle P E R F \_S e n s$, respectively, as well as time, investment objective and fund fixed effects. The two sensitivities are considered separately (Models 1 and 2) and together (Model 3). The results confirm that investment companies time both sensitivities with their repricing decisions: we see that expense ratio changes are positively correlat- 
ed with decreases in the expected price and performance sensitivities. ${ }^{19}$ Model 4 also considers, as possible explanatory variables, changes in the size of the mutual fund ( $\Delta$ Size $)$ and of the investment

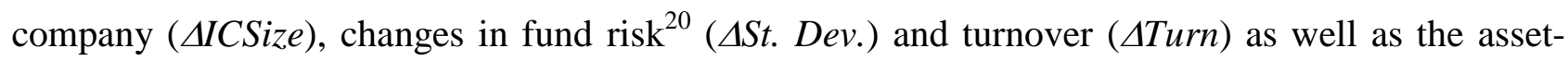
weighted average change in expense ratios for other funds managed by the same investment company ( $\Delta I n v$. Comp. Fee) or with the same investment objective ( $\triangle I n v$. Obj. Fee). The first four control variables should capture changes in the management cost of the fund due to a change in the incidence of fixed costs or to a different investment policy, while the last two should take care of investment company- and market-level effects. For example we could observe an increase in the demand of funds with a certain investment policy with a subsequent increase in the price not motivated by fund-level variables or we could see changes in a fund expense ratio due to bottom-line issues at the investment company level. The results of Model 4 confirm that the decision to change the expense ratio of a fund may be motivated by issues related to the economics of the whole investment company; nonetheless this effect does not reduce the significance of the main variables.

Tables 7 and 8 repeat the previous experiment with logistic regressions in which the dependent variable is a dummy set equal to one if the fund has increased or decreased the expense ratio, respectively. This new experiment allows us to separate the decision to change the expense ratio from the size of the said change. The previous results are fully confirmed in this new setting and the empirical relevance of sensitivity changes can be assessed considering the marginal effects of the two variables: there is a probability of $30 \%$ of observing an increase in the expense ratio for a fund that experienced a mean change in price sensitivity, but this probability rises to $39.2 \%$ for funds whose change in flow sensitivity to fees was in the lowest decile of the distribution (meaning either a de-

\footnotetext{
${ }^{19}$ The reader should remember that since expense ratios are expressed as a positive number a positive change in price sensitivity has to be interpreted as a reduction in price sensitivity: the relationship between flows and fees becomes "less negative."

${ }^{20}$ Normalized within the year/investment objective.
} 
crease in sensitivity or a low increase) and declines to $21.7 \%$ for those funds that experienced a high change in sensitivity (the top decile of the distribution, meaning a higher than average sensitivity increase). The probability of observing a decrease in the expense ratio is similarly affected: $46 \%$ for a mean change in sensitivity versus $36 \%$ when the change is in the highest decile and $56.5 \%$ when the change is in the lowest.

These numbers show that the changes in sensitivity of mutual fund flows to fund expenses sensibly alter repricing policies.

\section{[Insert Tables 7 and 8 about here]}

\subsection{Governance quality and repricing decisions}

Although the statistical relationship between the changes in the expected performance and price sensitivity and the subsequent changes in expense ratios is statistically evident, the fact that it is the fruit of an opportunistic repricing decision is, so far, just a speculation. Since the change in the compensation of the fund adviser requires a favorable vote from the board of directors (with the favor of the majority of the independent directors), this hypothesis can be tested by observing the extent to which the quality of the board itself, and that of the fund governance in general, affects the repricing behavior. The evidence in the previous literature on the ability of board of directors to protect investors' interests is somewhat sketchy: while Ding and Wermers (2009) show that independent directors increase the probability of ousting underperforming fund managers, the relationship between board quality and fee level is not clear. Tufano and Sevick (1997) find that independence of the board decreases fees, while Ferris and Yang (2007) do not find any evidence of a negative correlation between the fee level and the percentage of independent members on the board or the presence of an independent chairperson of the board. In this paper I argue that while the board 
quality may not affect the level of the expense ratio it may affect the "aggressiveness" of the changes in the expense ratio.

Since the end of 2004 Morningstar has collected data on the governance quality of major mutual funds or, as reported in the company publications, "the commitment of firms to fund shareholders." The so-called "Stewardship Grade" is a synthetic score that combines evaluations in five different $\operatorname{areas}^{21}$ : Regulatory History (past issues of the fund company with regulators, such as allegations of breaches of fiduciary duties), Board Quality (track record of board votes, investment of independent investors in the fund, etc.), Manager Incentives (investment of the manager in the fund and compensation structure), Corporate Culture (quality of disclosure, managerial focus on asset growth versus investment, etc.) and Fees (a relative analysis of the expense ratio within a group of peers).

Since the data history of these grades is fairly short I follow Gil-Bazo and Ruiz-Verdú (2009) and use the first available data point for all the observations prior to 2004. This methodology clearly generates a reverse causality problem, especially for the "Fee" component of the grade: less aggressive repricing policies would generate a subsequent high grade. In order to minimize this problem I use two different proxies for governance quality: $B O A R D$, the board quality component of the Morningstar Stewardship grade, and GOVERN, a synthetic grade built excluding the fee component. Table 9 reports the main results of a regression model in which the dependent variable is the change in the expense ratio and the independent variables include the governance quality measure and its interaction with the sensitivities' changes. The negative coefficient of the governance variables shows that better governance is, not surprisingly, associated with smaller increases in expense ratios. The coefficients of the interaction terms show that better governance is also associated with less aggressive repricing policies: a decrease in price sensitivity is associated with a lower increase

\footnotetext{
${ }^{21}$ For a detailed analysis of the score methodology see Morningstar (2006).
} 
in the expense ratio for funds with higher-quality governance (and the same is true for changes in performance sensitivity).

The results empirically confirm that the statistical relationship between changes in price (and performance) sensitivity and subsequent changes in expense ratios are indeed the fruit of opportunistic repricing behavior.

\section{[Insert Table 9 about here]}

\section{Conclusions}

In this paper, I analyze strategic repricing decisions for mutual fund management services. From the behavior of net investment flows for a large sample of US actively managed equity mutual funds from 1986 to 2006 I derive measures of performance and price sensitivity. Contrary to previous empirical research I show that investors do not consider expense ratios simply as a negative component of expected returns: their behavior shows a price sensitivity that is different and not always positively correlated with performance sensitivity. Specifically I show that while performance sensitivity monotonically increases with past performance, price sensitivity does not: investors who buy top past performers seem to be "distracted" by the fund's previous return and pay relatively little attention to the expense ratio. I also demonstrate that price sensitivity increases with fund visibility while performance sensitivity decreases. When search costs are high investors rely heavily, for their allocation decision, on the most widely available piece of information: the fund's past performance. When the fund becomes more visible other variables enter the decision process.

A third important result is related to the evolution of price and performance sensitivities through time. Looking at the data from 1986 to 2006 no discernible trend can be observed in the average performance sensitivity, while the price sensitivity strongly increases. This result shows that the 
dramatic increase in the availability of mutual funds' information for retail investors due to specialized providers has changed the investment decision process, increasing the relative importance of less-visible pieces of information such as expense ratios.

Finally I show that investment companies strategically time their repricing decisions in order to exploit time variations in price and performance sensitivities: increases in expense ratios are positively correlated with decreases in the expected sensitivity of investment flows to both performance and prices. The opportunistic nature of this behavior is confirmed by the fact that the repricing policies of mutual funds with high-quality governance are less aggressive.

\section{Acknowledgements}

I would like to thank an anonymous referee, Ike Mathur (the editor), Peter Tufano, Clemen Sialm, Javier Gil-Bazo, Andrea Resti and seminar participants at Bocconi University and at the University of Technology, Sydney and from the Financial Management Association, the European Financial Management Association, the Australasian Finance and Banking Conference, the Eastern Finance Association and the Midwest Finance Association for their helpful comments. The author gratefully acknowledges the financial support of the Centre for Applied Research in Finance (Carefin) of Bocconi University. 


\section{References}

Alexander, G., Jones, J., Nigro, P., 1998. Mutual fund shareholders: Characteristics, investor knowledge, and sources of information. Financial Services Review, 7(4), 301-316.

Arellano, M., Bond, S., 1991. Some tests of specification for panel data: Monte Carlo evidence and an application to employment equations, Review of Economic Studies, 58(2), 277-297.

Bailey, W., Kumar, A., Ng, D., 2010. Behavioral biases and mutual fund investors, mimeo.

Barber, B., Odean, T., Zheng, L., 2005. Out of sight, out of mind: The effects of expenses on mutual fund flows. Journal of Business, 78(6), 2095-2119.

Bergstresser, D., Chalmers, J., Tufano, P., 2009. Assessing the costs and benefits of brokers in the mutual fund industry. Review of Financial Studies, 22(12), 4129-4156.

Brown, K., Harlow, W.,Starks, L., 1996. Of tournaments and temptations: An analysis of managerial incentives in the mutual fund industry. Journal of Finance, 51(1), 85-110.

Capon, N., Fitzsimons, G., Prince, R., 1996. An individual level analysis of the mutual fund investment decisions. Journal of Financial Services Research, 10(1), 59-82.

Carhart, M., 1997. On persistence in mutual fund performance. Journal of Finance, 52(1), 57-82.

Cashman, G., Deli, D., Nardari F., Villupuram, S., 2007. Investor behavior in the mutual fund industry: Evidence from gross flows, mimeo.

Choi, J., Laibson, D., Madrian, B., 2010. Why does the law of one price fail? An experiment on index mutual funds. Review of Financial Studies, 23(4), 1405-1432.

Christoffersen, S., Musto, D., 2002. Demand curves and the pricing of money management. Review of Financial Studies, 15(5), 1499-1524.

Ding, B., Wermers, R., 2009. Mutual fund performance and governance structure: The role of portfolio managers and boards of directors, mimeo.

Elton, E., Gruber, M., Blake, C., 2001. A first look at the accuracy of the CRSP mutual fund database and a comparison of the CRSP and Morningstar mutual fund databases. Journal of Finance, 56(6), 2415-2430.

Fant, F., O’Neal, E., 2000. Temporal changes in the determinants of mutual fund flows. Journal of Financial Research, 23(3), 353-371.

Ferris, S., Yang, X., 2007. Do independent directors and chairmen matter? The role of boards of directors in mutual fund governance. Journal of Corporate Finance, 13(2-3), 392-420.

Gil-Bazo, J., Ruiz-Verdú, P., 2009. The relation between price and performance in the mutual fund industry. Journal of Finance, 64(5), 2153-2183. 
Hortaçsu, A., Syverson, C., 2004. Product differentiation, search costs, and competition in the mutual fund industry: A case study of S\&P 500 index funds. Quarterly Journal of Economics, 119(2), 403-456.

Huang, J., Wei K., Yan, H., 2007. Participation costs and the sensitivity of fund flows to past performance. Journal of Finance, 62(3), 1273-1311.

Iannotta, G., Navone, M., 2011. The cross-section of mutual fund fees dispersion, Journal of Banking and Finance, forthcoming.

Ippolito, R., 1992. Consumer reaction to measures of poor quality: Evidence from the mutual fund industry. Journal of Law and Economics, 35(1), 45-70.

Ivkovic, Z., Weisbenner, S., 2009. Individual investor mutual fund flows. Journal of Financial Economics, 92(2), 223-237.

Kempf, A., Ruenzi, S., 2008. Tournaments in mutual fund families. Review of Financial Studies, 21(2), 1013-1036.

Kempf, A., Ruenzi S., Thiele, T., 2009. Employment risk, compensation incentives, and managerial risk taking: Evidence from the mutual fund industry. Journal of Financial Economics, 92(1), 92108.

Kim, M., 2010. Changes in mutual fund flows and managerial incentives, mimeo.

Morningstar Inc., 2006. Fact sheet: The Morningstar Stewardship Grade for funds. URL http://corporate.morningstar.com/us/documents/stewardshipgradefunds/StewGradeMethodology_06 -18-07.pdf

Nanda, V., Wang, Z., Zheng, L., 2004. Family values and the star phenomenon: Strategies of mutual-fund families. Review of Financial Studies, 17(3), 667-98.

Nanda, V., Wang, Z., Zheng, L., 2009. The ABCs of mutual funds: On the introduction of multiple share classes. Journal of Financial Intermediation, 18(3), 329-361.

Navone, M., Pagani, M., 2009. Loads and investment decisions, CAREFIN Research Paper, 2/09.

O’Neal, E., 1999. Mutual fund share classes and broker incentives. Financial Analysts Journal, 55(5), 76-87.

Patel, J., Zeckhauser, R., Hendricks, D., 1994. Investment flows and performance: Evidence from mutual funds, cross-border investments, and new issues. In: Sato, R., Levich, R., Ramachandran, R. (eds.), Japan, Europe, and international financial markets: Analytical and empirical perspectives. Cambridge University Press, New York.

Sirri, E., Tufano, P., 1998. Costly search and mutual fund flows. Journal of Finance, 53(5), 15891622.

Tufano, P., Sevick, M., 1997. Board structure and fee-setting in the U.S. mutual fund industry. Journal of Financial Economics, 46(3), 321-355. 
Wilcox, R., 2003. Bargain hunting or star gazing? Investors' preferences for stock mutual funds. Journal of Business, 76(4), 645-663.

Zeckhauser, R., Patel, J., Hendricks, D., 1991. Nonrational actors and financial market behavior. Theory and Decision, 31, 257-87. 
Table 1

Summary statistics

This table reports summary statistics of our sample from 1986 to 2006 . At the end of each year, we calculate the crosssectional mean value of the total net asset value, fund age, expense ratio, annualized mean monthly return, standard deviation and net investment flow.

\begin{tabular}{|c|c|c|c|c|c|c|c|}
\hline Year & $\begin{array}{l}\text { Number of } \\
\text { Funds }\end{array}$ & $\begin{array}{c}\text { TNA } \\
\text { (Millions) }\end{array}$ & $\begin{array}{c}\text { Age } \\
\text { (Years) }\end{array}$ & $\begin{array}{c}\text { Expense } \\
\text { Ratio } \\
(\%)\end{array}$ & $\begin{array}{c}\text { Annualized } \\
\text { Return } \\
(\%)\end{array}$ & $\begin{array}{l}\text { Standard De- } \\
\text { viation }(\%)\end{array}$ & $\begin{array}{c}\text { Net Investment } \\
\text { Flow } \\
(\%)\end{array}$ \\
\hline 1986 & 246 & 367.3 & 24.7 & 0.89 & 23.90 & 4.49 & 16.10 \\
\hline 1987 & 276 & 434.8 & 23.4 & 0.95 & 11.25 & 6.71 & 14.28 \\
\hline 1988 & 311 & 503.7 & 22.7 & 1.05 & 4.60 & 5.60 & -6.82 \\
\hline 1989 & 358 & 434.0 & 21.3 & 1.16 & 23.58 & 3.24 & -2.27 \\
\hline 1990 & 381 & 497.1 & 21.4 & 1.15 & -3.61 & 4.78 & 5.14 \\
\hline 1991 & 444 & 430.3 & 20.0 & 1.04 & 28.60 & 4.62 & 15.18 \\
\hline 1992 & 413 & 590.5 & 21.0 & 1.16 & 11.18 & 3.86 & 24.57 \\
\hline 1993 & 621 & 580.6 & 17.6 & 1.21 & 16.85 & 2.65 & 31.26 \\
\hline 1994 & 818 & 597.1 & 14.9 & 1.27 & 2.40 & 3.04 & 25.79 \\
\hline 1995 & 1092 & 560.3 & 13.2 & 1.34 & 22.18 & 2.65 & 23.47 \\
\hline 1996 & 1312 & 621.4 & 12.4 & 1.37 & 19.82 & 3.12 & 30.96 \\
\hline 1997 & 1598 & 692.1 & 11.5 & 1.38 & 23.09 & 4.42 & 29.94 \\
\hline 1998 & 2025 & 743.8 & 10.5 & 1.43 & 10.77 & 5.93 & 25.34 \\
\hline 1999 & 2064 & 850.6 & 11.1 & 1.47 & 20.91 & 5.43 & 13.15 \\
\hline 2000 & 1720 & 962.6 & 10.3 & 1.52 & 21.85 & 6.68 & 19.20 \\
\hline 2001 & 1707 & 1164.7 & 10.9 & 1.54 & -18.18 & 6.85 & 12.55 \\
\hline 2002 & 2263 & 883.7 & 12.4 & 1.58 & -15.47 & 5.84 & 8.04 \\
\hline 2003 & 2282 & 727.4 & 13.1 & 1.60 & 15.19 & 4.72 & 3.99 \\
\hline 2004 & 2267 & 831.1 & 13.8 & 1.55 & 15.29 & 3.10 & 6.12 \\
\hline 2005 & 2158 & 1013.7 & 14.7 & 1.52 & 11.19 & 3.19 & -0.30 \\
\hline 2006 & 2062 & 1156.2 & 15.5 & 1.48 & 12.20 & 2.80 & -1.61 \\
\hline
\end{tabular}




\section{Table 2}

\section{Mutual fund alphas and factor loadings}

The table reports asset-weighted mean values and standard deviations (in parentheses) for the annualized alphas and factor loadings of our mutual funds from the Fama-French three-factor model and the Fama-French-Carhart fourfactor model. All the models have been estimated over four non-overlapping five-year periods of monthly returns.

\begin{tabular}{|c|c|c|c|c|c|c|c|c|c|}
\hline & \multicolumn{4}{|c|}{ Fama-French Three-Factor Model } & \multicolumn{5}{|c|}{ Fama-French-Carhart Four-Factor Model } \\
\hline & $\begin{array}{c}\text { Annualized } \\
\text { Alpha }\end{array}$ & Market & SMB & HML & $\begin{array}{c}\text { Annualized } \\
\text { Alpha }\end{array}$ & Market & SMB & HML & UMD \\
\hline \multirow[t]{2}{*}{ 1987-1991 } & 0.0037 & 0.8057 & 0.0167 & -0.0844 & 0.0105 & 0.8129 & -0.0309 & -0.1444 & -0.1128 \\
\hline & $(0.027)$ & $(0.153)$ & $(0.215)$ & $(0.368)$ & (0.028) & $(0.157)$ & $(0.205)$ & $(0.375)$ & (0.139) \\
\hline \multirow[t]{2}{*}{ 1992-1996 } & -0.0141 & 0.9336 & 0.0634 & 0.0309 & -0.0179 & 0.9245 & 0.0597 & 0.0259 & 0.0563 \\
\hline & $(0.025)$ & $(0.180)$ & $(0.266)$ & $(0.265)$ & $(0.029)$ & $(0.174)$ & $(0.263)$ & $(0.271)$ & $(0.174)$ \\
\hline \multirow[t]{2}{*}{ 1997-2001 } & -0.0138 & 0.9174 & 0.0160 & 0.1180 & -0.0124 & 0.9147 & 0.0173 & 0.1152 & -0.0082 \\
\hline & $(0.040)$ & $(0.168)$ & $(0.215)$ & $(0.372)$ & $(0.040)$ & $(0.166)$ & $(0.213)$ & $(0.353)$ & $(0.100)$ \\
\hline \multirow[t]{2}{*}{ 2002-2006 } & -0.0237 & 0.9552 & 0.0442 & -0.0140 & -0.0238 & 0.9645 & 0.0383 & -0.0210 & 0.0131 \\
\hline & (0.028) & $(0.183)$ & $(0.267)$ & $(0.289)$ & $(0.028)$ & $(0.183)$ & $(0.252)$ & $(0.305)$ & (0.097) \\
\hline
\end{tabular}


Table 3

Sensitivity to past performance and fee - Quadratic specification

The table reports the results of a series of panel regressions in which the dependent variable is the percentage net investment flow for fund $i$ in year $t$. The independent variables include, as a measure of performance, the fund fractional category ranking (Perf) and its squared value $\left(\operatorname{Perf}^{2}\right)$, the expense ratio of the fund (Exp) and its interactions with the performance measures (Perf $x$ Exp and Perf ${ }^{2} x$ Exp). In Models 4-7 the performance and expenses are interacted with four proxy measures for fund visibility: (the natural log of) the fund size (Size), age (Age) and investment company size (ICSize) and the number of fund categories in which the investment company is active (ICCat). In all the models the fund-level control variables include: (the natural $\log$ of) the fund size, age and investment company size, the number of investment categories in which the investment company is active, dummy variables for load funds and funds that belong to a star family, fund standard deviation and the average flow in funds with the same investment objective. All the models also include the lagged value of fund flows $\left(\right.$ Flow $\left._{t-1}\right)$ as an explanatory variable. All the independent variables are measured in year $t-1$ and all the variables are defined as excess value over the mean of all the funds with the same investment objective in year $t$ - 1 . Each model includes individual fund and investment objective fixed effects. Standard errors are clustered at the fund level. ***,** and * represent significance at the $1 \%, 5 \%$ and $10 \%$ levels, respectively. PValues in parentheses.

\begin{tabular}{|c|c|c|c|c|c|c|c|}
\hline & (a.1) & (a.2) & (a.3) & (a.4) & (a.5) & (a.6) & (a.7) \\
\hline Flow $_{t-1}$ & $\begin{array}{c}0.091 * * * \\
(0.000)\end{array}$ & $\begin{array}{c}0.114 * * * \\
(0.000)\end{array}$ & $\begin{array}{c}0.088^{* * * *} \\
(0.000)\end{array}$ & $\begin{array}{c}0.082 * * * \\
(0.000)\end{array}$ & $\begin{array}{c}0.079 * * * \\
(0.000)\end{array}$ & $\begin{array}{c}0.088 * * * \\
(0.000)\end{array}$ & $\begin{array}{c}0.088 * * * \\
(0.000)\end{array}$ \\
\hline Perf & $\begin{array}{c}0.204 * * * \\
(0.000)\end{array}$ & & $\begin{array}{c}0.203 * * * \\
(0.000)\end{array}$ & $\begin{array}{c}0.209 * * * \\
(0.000)\end{array}$ & $\begin{array}{c}0.213 * * * \\
(0.000)\end{array}$ & $\begin{array}{c}0.202 * * * \\
(0.000)\end{array}$ & $\begin{array}{c}0.169 * * * \\
(0.000)\end{array}$ \\
\hline Perf $^{2}$ & $\begin{array}{c}0.244 * * * \\
(0.000)\end{array}$ & & $\begin{array}{c}0.259 * * * \\
(0.000)\end{array}$ & $\begin{array}{c}0.264 * * * \\
(0.000)\end{array}$ & $\begin{array}{c}0.257 * * * \\
(0.000)\end{array}$ & $\begin{array}{c}0.256^{* * * *} \\
(0.000)\end{array}$ & $\begin{array}{c}0.258^{* * * *} \\
(0.000)\end{array}$ \\
\hline Exp & & $\begin{array}{c}-15.674 * * * \\
(0.000)\end{array}$ & $\begin{array}{c}-16.574 * * * \\
(0.000)\end{array}$ & $\begin{array}{c}-20.408^{* * *} \\
(0.000)\end{array}$ & $\begin{array}{c}-18.480 * * * \\
(0.000)\end{array}$ & $\begin{array}{c}-16.916 * * * \\
(0.000)\end{array}$ & $\begin{array}{c}-11.763 * * * \\
(0.000)\end{array}$ \\
\hline Perf $\times$ Exp & & $\begin{array}{c}15.725^{* * *} \\
(0.000)\end{array}$ & $\begin{array}{c}14.653 \text { *** } \\
(0.000)\end{array}$ & $\begin{array}{c}11.407^{* * *} \\
(0.000)\end{array}$ & $\begin{array}{c}10.686^{* * * *} \\
(0.000)\end{array}$ & $\begin{array}{c}14.917 \text { *** } \\
(0.000)\end{array}$ & $\begin{array}{c}14.641^{* * *} \\
(0.000)\end{array}$ \\
\hline $\operatorname{Perf}^{2} \times \operatorname{Exp}$ & & $\begin{array}{c}18.376^{* *} \\
(0.013)\end{array}$ & $\begin{array}{c}24.804 * * * \\
(0.001)\end{array}$ & $\begin{array}{c}22.816^{* * *} \\
(0.002)\end{array}$ & $\begin{array}{c}23.739 * * * \\
(0.001)\end{array}$ & $\begin{array}{c}25.072 * * * \\
(0.001)\end{array}$ & $\begin{array}{c}24.811 * * * \\
(0.001)\end{array}$ \\
\hline Perf $\times$ Size & & & & $\begin{array}{c}-0.028^{* * *} \\
(0.000)\end{array}$ & & & \\
\hline Exp $\times$ Size & & & & $\begin{array}{c}-8.722 * * * \\
(0.000)\end{array}$ & & & \\
\hline Perf $\times$ Age & & & & & $\begin{array}{c}-0.061 * * * \\
(0.000)\end{array}$ & & \\
\hline Exp $\times$ Age & & & & & $\begin{array}{c}-10.809 * * * \\
(0.000)\end{array}$ & & \\
\hline Perf $\times$ ICSize & & & & & & $\begin{array}{c}0.003 \\
(0.470)\end{array}$ & \\
\hline Exp $\times$ ICSize & & & & & & $\begin{array}{c}-1.906^{* * *} \\
(0.000)\end{array}$ & \\
\hline Perf $\times$ ICCat & & & & & & & $\begin{array}{l}0.009 * \\
(0.094)\end{array}$ \\
\hline Exp $\times$ ICCat & & & & & & & $\begin{array}{c}-1.350 * * \\
(0.028)\end{array}$ \\
\hline Fund Controls & $\mathrm{Y}$ & $Y$ & $\mathrm{Y}$ & $\mathrm{Y}$ & $\mathrm{Y}$ & $\mathrm{Y}$ & $\mathrm{Y}$ \\
\hline Fund FE & $\mathrm{Y}$ & $\mathrm{Y}$ & $\mathrm{Y}$ & $\mathrm{Y}$ & $\mathrm{Y}$ & $\mathrm{Y}$ & $\mathrm{Y}$ \\
\hline No. of Obs. & 22,702 & 22,702 & 22,702 & 22,702 & 22,702 & 22,702 & 22,702 \\
\hline
\end{tabular}




\section{Table 4}

\section{Sensitivity to past performance and fee - Dummy variable specification}

The table reports the results of a series of panel regressions in which the dependent variable is the percentage net investment flow for fund $i$ in year $t$. The independent variables include, as a measure of performance, the fund fractional category ranking (Perf) and its interactions with two dummy variables set equal to 1 if in $t-1$ the fund was in the top (High) or middle (Mid) third of its category ranking, the expense ratio of the fund (Exp) and its interactions with the performance dummy variables (Exp x High and Exp x Mid). In Models 4-7 the performance and expenses are interacted with four proxy measures for fund visibility: (the natural log of) the fund size (Size), age (Age) and investment company size (ICSize) and the number of fund categories in which the investment company is active (ICCat). In all the models the fund-level control variables include: (the natural log of) the fund size, age and investment company size, the number of investment categories in which the investment company is active, dummy variables for load funds, funds that belong to a star family and funds that in the previous year were in the top and middle thirds of their ranking distribution, fund standard deviation and the average flow in funds with the same investment objective. All the models also include the lagged value of fund flows $\left(\right.$ Flow $\left._{t-1}\right)$ as an explanatory variable. All the independent variables are measured in year $t-1$ and all the variables are defined as excess value over the mean of all the funds with the same investment objective in year $t$ - 1 . Each model includes time, investment objective and individual fund and investment objective fixed effects. Standard errors are clustered at the fund level. $* * *, * *$ and * represent significance at the $1 \%, 5 \%$ and $10 \%$ levels, respectively. P-Values in parentheses.

\begin{tabular}{|c|c|c|c|c|c|c|c|}
\hline & (a.1) & (a.2) & (a.3) & (a.4) & (a.5) & (a.6) & (a.7) \\
\hline Flow $_{t-1}$ & $\begin{array}{c}0.090^{* * * *} \\
(0.000)\end{array}$ & $\begin{array}{c}0.095^{* * * *} \\
(0.000)\end{array}$ & $\begin{array}{c}0.088^{* * * *} \\
(0.000)\end{array}$ & $\begin{array}{c}0.082 * * * \\
(0.000)\end{array}$ & $\begin{array}{c}0.078 * * * \\
(0.000)\end{array}$ & $\begin{array}{c}0.088^{* * * *} \\
(0.000)\end{array}$ & $\begin{array}{c}0.088 * * * \\
(0.000)\end{array}$ \\
\hline Perf & $\begin{array}{c}0.065 \\
(0.187)\end{array}$ & & $\begin{array}{c}0.044 \\
(0.371)\end{array}$ & $\begin{array}{c}0.050 \\
(0.307)\end{array}$ & $\begin{array}{c}0.062 \\
(0.205)\end{array}$ & $\begin{array}{c}0.044 \\
(0.368)\end{array}$ & $\begin{array}{c}0.058 \\
(0.443)\end{array}$ \\
\hline Perf $\times$ Mid & $\begin{array}{c}0.153^{* * *} \\
(0.023)\end{array}$ & & $\begin{array}{c}0.172 * * \\
(0.010)\end{array}$ & $\begin{array}{c}0.176^{* * * *} \\
(0.008)\end{array}$ & $\begin{array}{c}0.177 \text { **** } \\
(0.008)\end{array}$ & $\begin{array}{c}0.174 * * * \\
(0.010)\end{array}$ & $\begin{array}{c}0.171^{* *} \\
(0.011)\end{array}$ \\
\hline Perf $\times$ High & $\begin{array}{c}0.417 * * * \\
(0.000)\end{array}$ & & $\begin{array}{c}0.434 * * * \\
(0.000)\end{array}$ & $\begin{array}{c}0.446 * * * \\
(0.000)\end{array}$ & $\begin{array}{c}0.435 * * * \\
(0.000)\end{array}$ & $\begin{array}{c}0.433 * * * \\
(0.000)\end{array}$ & $\begin{array}{c}0.436 * * * \\
(0.000)\end{array}$ \\
\hline Exp & & $\begin{array}{c}-18.736^{* * * *} \\
(0.000)\end{array}$ & $\begin{array}{c}-18.883 * * * * \\
(0.000)\end{array}$ & $\begin{array}{c}-22.187 * * * \\
(0.000)\end{array}$ & $\begin{array}{c}-19.996 * * * \\
(0.000)\end{array}$ & $\begin{array}{c}-19.281 * * * \\
(0.000)\end{array}$ & $\begin{array}{c}-14.087 * * * \\
(0.000)\end{array}$ \\
\hline Exp $\times$ Mid & & $\begin{array}{c}3.369^{* *} \\
(0.010)\end{array}$ & $\begin{array}{c}3.394 * * * \\
(0.009)\end{array}$ & $\begin{array}{c}2.942 * * \\
(0.042)\end{array}$ & $\begin{array}{l}2.607^{*} \\
(0.063)\end{array}$ & $\begin{array}{c}3.442 * * * \\
(0.009)\end{array}$ & $\begin{array}{c}3.406 * * * \\
(0.009)\end{array}$ \\
\hline Exp $\times$ High & & $\begin{array}{c}10.523^{* * * *} \\
(0.000)\end{array}$ & $\begin{array}{c}10.043 * * * \\
(0.000)\end{array}$ & $\begin{array}{c}8.259 * * * \\
(0.000)\end{array}$ & $\begin{array}{c}8.014 * * * \\
(0.000)\end{array}$ & $\begin{array}{c}10.287 * * * \\
(0.000)\end{array}$ & $\begin{array}{c}9.990 * * * \\
(0.000)\end{array}$ \\
\hline Perf $\times$ Size & & & & $\begin{array}{c}-0.058^{* * * *} \\
(0.000)\end{array}$ & & & \\
\hline Exp $\times$ Size & & & & $\begin{array}{c}-8.731 \text { *** } \\
(0.000)\end{array}$ & & & \\
\hline Perf $\times$ Age & & & & & $\begin{array}{c}-0.149^{* * *} \\
(0.000)\end{array}$ & & \\
\hline Exp $\times$ Age & & & & & $\begin{array}{c}-10.874 * * * \\
(0.000)\end{array}$ & & \\
\hline Perf $\times$ ICSize & & & & & & $\begin{array}{l}-0.011 \\
(0.352)\end{array}$ & \\
\hline $\operatorname{Exp} \times$ ICSize & & & & & & $\begin{array}{c}-1.903 * * * \\
(0.000)\end{array}$ & \\
\hline Perf $\times$ ICCat & & & & & & & $\begin{array}{l}-0.004 \\
(0.811)\end{array}$ \\
\hline $\operatorname{Exp} \times$ ICCat & & & & & & & $\begin{array}{c}-1.337 * * \\
(0.030) \\
\end{array}$ \\
\hline Fund Controls & $\mathrm{Y}$ & $\mathrm{Y}$ & $\mathrm{Y}$ & $\mathrm{Y}$ & $\mathrm{Y}$ & $\mathrm{Y}$ & $\mathrm{Y}$ \\
\hline Fund FE & $\mathrm{Y}$ & $\mathrm{Y}$ & $\mathrm{Y}$ & $\mathrm{Y}$ & $\mathrm{Y}$ & $\mathrm{Y}$ & $\mathrm{Y}$ \\
\hline No. of Obs. & 22,702 & 22,702 & 22,702 & 22,702 & 22,702 & 22,702 & 22,702 \\
\hline
\end{tabular}


Table 5

Changes in expense ratios

This table reports summary statistics of changes in expense ratios in our sample from 1986 to 2006.

\begin{tabular}{|c|c|c|c|c|c|c|c|}
\hline \multirow[b]{2}{*}{ Year } & \multirow{2}{*}{$\begin{array}{c}\% \text { of } \\
\text { Increases }\end{array}$} & \multirow{2}{*}{$\begin{array}{c}\% \text { of } \\
\text { Decreases }\end{array}$} & \multicolumn{5}{|c|}{$\%$ Change in the Expense Ratio } \\
\hline & & & Mean & Median & 10th Pctile & 90th Pctile & $\begin{array}{l}\text { Standard } \\
\text { Deviation }\end{array}$ \\
\hline 1986 & 22.36 & 60.16 & -3.07 & -3.14 & -15.48 & 8.33 & 11.31 \\
\hline 1987 & 42.03 & 45.29 & 1.33 & 0.00 & -14.86 & 17.57 & 14.50 \\
\hline 1988 & 65.27 & 23.79 & 6.24 & 4.63 & -7.69 & 24.49 & 15.29 \\
\hline 1989 & 39.39 & 46.93 & 2.38 & 0.00 & -10.48 & 20.27 & 14.35 \\
\hline 1990 & 46.19 & 39.63 & 1.09 & 0.00 & -12.50 & 16.67 & 13.04 \\
\hline 1991 & 29.95 & 53.83 & -5.21 & -1.41 & -33.16 & 10.78 & 16.74 \\
\hline 1992 & 38.50 & 49.88 & 2.23 & 0.00 & -12.95 & 27.66 & 15.90 \\
\hline 1993 & 31.56 & 55.39 & -0.54 & -1.22 & -12.35 & 13.51 & 11.66 \\
\hline 1994 & 40.71 & 44.01 & 0.58 & 0.00 & -9.76 & 11.11 & 11.01 \\
\hline 1995 & 21.89 & 28.48 & 0.15 & 0.00 & -5.43 & 5.00 & 7.13 \\
\hline 1996 & 15.17 & 28.13 & -0.84 & 0.00 & -6.90 & 2.17 & 7.07 \\
\hline 1997 & 23.47 & 62.52 & -3.07 & -2.36 & -14.93 & 4.93 & 11.03 \\
\hline 1998 & 19.21 & 32.35 & -0.47 & 0.00 & -5.38 & 3.19 & 7.15 \\
\hline 1999 & 37.40 & 47.38 & -0.34 & 0.00 & -8.33 & 7.14 & 8.05 \\
\hline 2000 & 37.44 & 47.44 & -0.38 & 0.00 & -8.00 & 6.36 & 7.33 \\
\hline 2001 & 52.72 & 30.99 & 1.48 & 0.54 & -4.88 & 8.29 & 7.25 \\
\hline 2002 & 63.32 & 20.15 & 3.04 & 1.77 & -2.67 & 10.38 & 7.38 \\
\hline 2003 & 59.68 & 20.29 & 2.53 & 1.33 & -2.34 & 9.35 & 6.55 \\
\hline 2004 & 15.66 & 68.81 & -2.81 & -2.07 & -9.09 & 1.54 & 5.57 \\
\hline 2005 & 28.22 & 56.16 & -1.53 & -0.88 & -7.14 & 3.09 & 5.80 \\
\hline 2006 & 21.29 & 61.15 & -1.66 & -1.05 & -6.12 & 2.00 & 4.79 \\
\hline Total & 34.93 & 43.24 & -0.17 & 0.00 & -7.79 & 7.14 & 8.64 \\
\hline
\end{tabular}




\section{Table 6}

\section{Changes in expense ratios}

This table reports the results of panel regressions in which the dependent variable is the difference between the expense ratios charged by each mutual fund in the years $t$ and $t-1$. $\triangle P R I C E \_S e n s$ and $\triangle P E R F \_S e n s$ are the changes in the expected price and performance sensitivities of fund shareholders between year $t$ and year $t-1$ calculated on the base of the estimated coefficients of the quadratic model in Table 3 and the dummy variable model in Table 4. $\Delta$ Size and $\Delta I C S i z e$ are the changes, between year $t$ and year $t-1$, in the asset under management of the fund and of its management company, respectively. $\Delta S t$. Dev. and $\Delta T$ Trn are the changes, between year $t$ and year $t-1$, of the standard deviation and the turnover of the fund. $\Delta I n v$. Obj. Fee and $\Delta I n v$. Comp. Fee are the asset-weighted average changes in expense ratios for funds with the same investment objective or managed by the same investment company, respectively. Each model includes time and investment objective fixed effects. Standard errors are clustered at the fund level. ***,** and * represent significance at the $1 \%, 5 \%$ and $10 \%$ levels, respectively. P-Values in parentheses.

\begin{tabular}{|c|c|c|c|c|c|c|c|c|}
\hline & \multicolumn{4}{|c|}{ Panel A - Quadratic Model } & \multicolumn{4}{|c|}{ Panel B - Dummy Variable Model } \\
\hline & (a.1) & (a.2) & (a.3) & (a.4) & (b.1) & (b.2) & (b.3) & (b.4) \\
\hline Constant & $\begin{array}{c}-0.010 * * * \\
(0.000)\end{array}$ & $\begin{array}{l}-0.004 * \\
(0.057)\end{array}$ & $\begin{array}{c}0.002 \\
(0.318)\end{array}$ & $\begin{array}{c}0.006 * * * \\
(0.007)\end{array}$ & $\begin{array}{c}-0.010^{* * *} \\
(0.000)\end{array}$ & $\begin{array}{c}-0.006 \text { *** } \\
(0.007)\end{array}$ & $\begin{array}{c}0.002 \\
(0.359)\end{array}$ & $\begin{array}{c}0.008 * * * \\
(0.000)\end{array}$ \\
\hline$\Delta$ PERF_Sens & $\begin{array}{c}-0.036^{* * *} \\
(0.000)\end{array}$ & & $\begin{array}{c}-0.050 * * * \\
(0.000)\end{array}$ & $\begin{array}{c}-0.044 * * * \\
(0.000)\end{array}$ & $\begin{array}{c}-0.027 * * * \\
(0.000)\end{array}$ & & $\begin{array}{c}-0.044 * * * \\
(0.000)\end{array}$ & $\begin{array}{c}-0.041^{* * *} \\
(0.000)\end{array}$ \\
\hline$\Delta$ PRICE_Sens & & $\begin{array}{c}0.001^{* * *} * \\
(0.000)\end{array}$ & $\begin{array}{c}0.002 * * * \\
(0.000)\end{array}$ & $\begin{array}{c}0.002 * * * \\
(0.000)\end{array}$ & & $\begin{array}{c}0.001 * * * \\
(0.001)\end{array}$ & $\begin{array}{c}0.002^{* * * *} \\
(0.000)\end{array}$ & $\begin{array}{c}0.002 * * * \\
(0.000)\end{array}$ \\
\hline$\Delta$ Size & & & & $\begin{array}{c}-0.000 * * \\
(0.022)\end{array}$ & & & & $\begin{array}{c}-0.000^{* *} \\
(0.030)\end{array}$ \\
\hline$\Delta \mathrm{ICSize}$ & & & & $\begin{array}{c}-0.000^{* * * *} \\
(0.010)\end{array}$ & & & & $\begin{array}{c}-0.000 \text { *** } \\
(0.000)\end{array}$ \\
\hline$\Delta$ Turn & & & & $\begin{array}{c}0.001 \\
(0.768)\end{array}$ & & & & $\begin{array}{c}0.002 \\
(0.344)\end{array}$ \\
\hline$\Delta$ St. Dev. & & & & $\begin{array}{c}-0.002 * * \\
(0.022)\end{array}$ & & & & $\begin{array}{c}-0.002 * * \\
(0.026)\end{array}$ \\
\hline$\Delta$ Inv. Obj. Fee & & & & $\begin{array}{c}0.140 \\
(0.163)\end{array}$ & & & & $\begin{array}{c}0.149 \\
(0.123)\end{array}$ \\
\hline$\Delta$ Inv. Comp. Fee & & & & $\begin{array}{c}0.406^{* * * *} \\
(0.000)\end{array}$ & & & & $\begin{array}{c}0.410^{* * * *} \\
(0.000)\end{array}$ \\
\hline No. of Obs. & 23,004 & 23,004 & 23,004 & 23,004 & 23,004 & 23,004 & 23,004 & 23,004 \\
\hline Adjusted $\mathrm{R}^{2}$ & 0.067 & 0.062 & 0.071 & 0.165 & 0.062 & 0.060 & 0.066 & 0.157 \\
\hline
\end{tabular}


Table 7

Probability of increasing expense ratios

This table reports the results of logistic regressions in which the dependent variable is a dummy set equal to one if the difference between the expense ratios charged by a mutual fund in years $t$ and $t-1$ is positive. $\triangle P R I C E \_S e n s$ and $\triangle P E R F \_$Sens are the changes in the expected price and performance sensitivities of fund shareholders between year $t$ and year $t-1$ calculated on the base of the estimated coefficients of the quadratic model in Table 3 and the dummy variable model in Table 4. $\Delta$ Size and $\Delta I C$ Size are the changes, between year $t$ and year $t$ - 1 , in the asset under management of the fund and of its management company, respectively. $\Delta$ St. Dev. and $\Delta$ Turn are the changes, between year $t$ and year $t$ 1 , in the standard deviation and the turnover of the fund. \%Inv. Obj. Inc and \%Inv. Comp. Inc are the asset-weighted percentages of funds with the same investment objective (or managed by the same investment company) that increased the expense ratio between $t$ and $t$ - 1 . Each model includes time and investment objective fixed effects. Standard errors are clustered at the fund level. $* * *, * *$ and $*$ represent significance at the $1 \%, 5 \%$ and $10 \%$ levels, respectively. PValues in parentheses.

\begin{tabular}{|c|c|c|c|c|c|c|c|c|}
\hline & \multicolumn{4}{|c|}{ Panel A - Quadratic Model } & \multicolumn{4}{|c|}{ Panel B - Dummy Variable Model } \\
\hline & (a.1) & (a.2) & (a.3) & (a.4) & (b.1) & $(\mathrm{b} .2)$ & (b.3) & (b.4) \\
\hline Constant & $\begin{array}{c}-1.279 * * * \\
(0.000)\end{array}$ & $\begin{array}{c}-1.192 * * * \\
(0.000)\end{array}$ & $\begin{array}{c}-0.907 * * * \\
(0.000)\end{array}$ & $\begin{array}{c}-1.814 * * * \\
(0.000)\end{array}$ & $\begin{array}{c}-1.332 * * * \\
(0.000)\end{array}$ & $\begin{array}{c}-1.227 * * * \\
(0.000)\end{array}$ & $\begin{array}{c}-0.984 * * * \\
(0.000)\end{array}$ & $\begin{array}{c}-1.853^{* * *} \\
(0.000)\end{array}$ \\
\hline$\Delta$ PERF_Sens & $\begin{array}{c}-0.702 * * * \\
(0.000)\end{array}$ & & $\begin{array}{c}-0.982^{* * * *} \\
(0.000)\end{array}$ & $\begin{array}{c}-0.985^{* * *} \\
(0.000)\end{array}$ & $\begin{array}{c}-0.558 * * * \\
(0.000)\end{array}$ & & $\begin{array}{c}-0.928 * * * \\
(0.000)\end{array}$ & $\begin{array}{c}-0.942^{* * * *} \\
(0.000)\end{array}$ \\
\hline$\Delta$ PRICE_Sens & & $\begin{array}{c}0.018^{* * *} \\
(0.000)\end{array}$ & $\begin{array}{c}0.049 * * * \\
(0.000)\end{array}$ & $\begin{array}{c}0.045^{* * *} \\
(0.000)\end{array}$ & & $\begin{array}{c}0.012 * * * \\
(0.001)\end{array}$ & $\begin{array}{c}0.049 * * * \\
(0.000)\end{array}$ & $\begin{array}{c}0.044^{* * *} * \\
(0.000)\end{array}$ \\
\hline$\Delta$ Size & & & & $\begin{array}{c}-0.000^{* * *} \\
(0.004)\end{array}$ & & & & $\begin{array}{c}-0.000 * * * \\
(0.004)\end{array}$ \\
\hline$\Delta \mathrm{ICSize}$ & & & & $\begin{array}{c}0.000 \\
(0.884)\end{array}$ & & & & $\begin{array}{l}-0.000 \\
(0.700)\end{array}$ \\
\hline$\Delta$ Turn & & & & $\begin{array}{c}0.075 * * \\
(0.042)\end{array}$ & & & & $\begin{array}{c}0.084^{* *} \\
(0.017)\end{array}$ \\
\hline$\Delta$ St. Dev. & & & & $\begin{array}{c}-0.046^{* *} \\
(0.014)\end{array}$ & & & & $\begin{array}{c}-0.048^{* * *} \\
(0.008)\end{array}$ \\
\hline \%Inv. Obj. Inc & & & & $\begin{array}{c}0.656^{* *} \\
(0.029)\end{array}$ & & & & $\begin{array}{l}0.538^{*} \\
(0.066)\end{array}$ \\
\hline \%Inv. Comp. Inc & & & & $\begin{array}{c}2.710^{* * * *} \\
(0.000)\end{array}$ & & & & $\begin{array}{c}2.692 * * * \\
(0.000) \\
\end{array}$ \\
\hline No. of Obs. & 23,004 & 23,004 & 23,004 & 23,004 & 23,004 & 23,004 & 23,004 & 23,004 \\
\hline Pseudo $\mathrm{R}^{2}$ & 0.095 & 0.090 & 0.100 & 0.232 & 0.093 & 0.089 & 0.097 & 0.228 \\
\hline
\end{tabular}




\section{Table 8}

\section{Probability of decreasing expense ratios}

This table reports the results of logistic regressions in which the dependent variable is a dummy set equal to one if the difference between the expense ratios charged by a mutual fund in years $t$ and $t-1$ is negative. $\triangle P R I C E \_S e n s$ and $\triangle P E R F \_$Sens are the changes in the expected price and performance sensitivities of fund shareholders between year $t$ and year $t-1$ calculated on the base of the estimated coefficients of the quadratic model in Table 3 and the dummy variable model in Table 4. $\Delta$ Size and $\Delta I C$ Size are the changes, between year $t$ and year $t-1$, in the asset under management of the fund and its management company, respectively. $\Delta S$. Dev. and $\Delta T u r n$ are the changes, between year $t$ and year $t-1$, in the standard deviation and the turnover of the fund. \%Inv. Obj. Dec and \%Inv. Comp. Dec are the asset-weighted percentages of funds with the same investment objective (or managed by the same investment company) that decreased the expense ratio between $t$ and $t$-1. Each model includes time and investment objective fixed effects. Standard errors are clustered at the fund level. $* * *, * *$ and $*$ represent significance at the $1 \%, 5 \%$ and $10 \%$ levels, respectively. P-Values in parentheses.

\begin{tabular}{|c|c|c|c|c|c|c|c|c|}
\hline & \multicolumn{4}{|c|}{ Panel A - Quadratic Model } & \multicolumn{4}{|c|}{ Panel B - Dummy Variable Model } \\
\hline & (a.1) & (a.2) & (a.3) & (a.4) & (b.1) & (b.2) & (b.3) & (b.4) \\
\hline \multirow[t]{2}{*}{ Constant } & $0.495 * * *$ & $0.412 * * *$ & $0.160 * *$ & $-2.025 * * *$ & $0.560 * * *$ & $0.464 * * *$ & $0.255^{* * *}$ & $-1.899 * * *$ \\
\hline & $(0.000)$ & $(0.000)$ & $(0.015)$ & $(0.000)$ & $(0.000)$ & $(0.000)$ & $(0.000)$ & $(0.000)$ \\
\hline \multirow[t]{2}{*}{$\Delta$ PERF_Sens } & $0.669 * * *$ & & $0.914 * * *$ & $0.860 * * *$ & $0.548 * * *$ & & $0.864 * * *$ & $0.816^{* * * *}$ \\
\hline & $(0.000)$ & & $(0.000)$ & $(0.000)$ & $(0.000)$ & & $(0.000)$ & $(0.000)$ \\
\hline \multirow[t]{2}{*}{$\triangle$ PRICE_Sens } & & $-0.017 * * *$ & $-0.044 * * *$ & $-0.044 * * *$ & & $-0.011 * * *$ & $-0.042 * * *$ & $-0.043 * * *$ \\
\hline & & $(0.000)$ & $(0.000)$ & $(0.000)$ & & $(0.001)$ & $(0.000)$ & $(0.000)$ \\
\hline \multirow[t]{2}{*}{$\Delta$ Size } & & & & $0.000 * *$ & & & & $0.000 * *$ \\
\hline & & & & $(0.018)$ & & & & $(0.018)$ \\
\hline \multirow[t]{2}{*}{$\Delta \mathrm{ICSize}$} & & & & $0.000 * *$ & & & & $0.000 * * *$ \\
\hline & & & & $(0.015)$ & & & & $(0.001)$ \\
\hline \multirow[t]{2}{*}{$\Delta$ Turn } & & & & $-0.059 *$ & & & & $-0.077 * *$ \\
\hline & & & & $(0.082)$ & & & & $(0.016)$ \\
\hline \multirow[t]{2}{*}{$\Delta$ St. Dev. } & & & & $0.055^{* * *} *$ & & & & $0.060 * * *$ \\
\hline & & & & $(0.002)$ & & & & $(0.000)$ \\
\hline \multirow[t]{2}{*}{ \%Inv. Obj. Dec } & & & & $1.076 * * *$ & & & & $1.005^{* * *}$ \\
\hline & & & & $(0.001)$ & & & & $(0.002)$ \\
\hline \multirow[t]{2}{*}{ \%Inv. Comp. Dec } & & & & $2.630 * * *$ & & & & $2.626^{* * * *}$ \\
\hline & & & & $(0.000)$ & & & & $(0.000)$ \\
\hline No. of Obs. & 23,004 & 23,004 & 23,004 & 23,004 & 23,004 & 23,004 & 23,004 & 23,004 \\
\hline Pseudo $\mathrm{R}^{2}$ & 0.090 & 0.085 & 0.094 & 0.224 & 0.085 & 0.081 & 0.089 & 0.220 \\
\hline
\end{tabular}


Table 9

\section{Governance quality and repricing decisions}

This table reports the results of panel regressions in which the dependent variable is the difference between the expense ratios charged by each mutual fund in years $t$ and $t-1$. $\triangle P R I C E \_S e n s$ and $\triangle P E R F \_S e n s$ are the changes in the expected price and performance sensitivities of fund shareholders between year $t$ and year $t-1$ calculated on the base of the estimated coefficients of the quadratic model in Table 3. GOVERN is the Morningstar Stewardship Grade (excluding the Fee component) and BOARD is the Board Quality component of the Morningstar Stewardship Grade. $\triangle$ Size and $\triangle I C S i z e$ are the changes, between year $t$ and year $t-1$, in the asset under management of the fund and its management company, respectively. $\Delta S t$. Dev. is the change, between year $t$ and year $t-1$, in the standard deviation and the turnover of the fund. AInv. Obj. Fee and LInv. Comp. Fee are the asset-weighted average changes in expense ratios for funds with the same investment objective or managed by the same investment company, respectively. Each model includes time and investment objective fixed effects. Standard errors are clustered at the fund level. ***,** and * represent significance at the $1 \%, 5 \%$ and $10 \%$ levels, respectively. P-Values in parentheses.

\begin{tabular}{|c|c|c|c|c|c|c|c|c|}
\hline & (1) & (2) & (3) & (4) & (5) & (6) & (7) & (8) \\
\hline Constant & $\begin{array}{c}0.015^{* * * *} \\
(0.000)\end{array}$ & $\begin{array}{c}0.015^{* * * *} \\
(0.001)\end{array}$ & $\begin{array}{c}0.023 * * * \\
(0.000)\end{array}$ & $\begin{array}{c}0.024 * * * \\
(0.000)\end{array}$ & $\begin{array}{c}0.013 * * * \\
(0.001)\end{array}$ & $\begin{array}{c}0.013 * * * \\
(0.001)\end{array}$ & $\begin{array}{c}0.021 * * * \\
(0.000)\end{array}$ & $\begin{array}{c}0.022 * * * \\
(0.000)\end{array}$ \\
\hline$\triangle$ PERF_Sens & $\begin{array}{c}-0.049 * * * \\
(0.000)\end{array}$ & $\begin{array}{c}-0.079 * * * \\
(0.000)\end{array}$ & $\begin{array}{c}-0.049 * * * \\
(0.000)\end{array}$ & $\begin{array}{c}-0.087 * * * \\
(0.000)\end{array}$ & $\begin{array}{c}-0.049 * * * \\
(0.000)\end{array}$ & $\begin{array}{c}-0.081 * * * \\
(0.000)\end{array}$ & $\begin{array}{c}-0.049 * * * \\
(0.000)\end{array}$ & $\begin{array}{c}-0.088 \text { *** } \\
(0.000)\end{array}$ \\
\hline$\Delta$ PRICE_Sens & $\begin{array}{c}0.002 * * * \\
(0.000)\end{array}$ & $\begin{array}{c}0.002 * * * \\
(0.000)\end{array}$ & $\begin{array}{c}0.004 * * * \\
(0.000)\end{array}$ & $\begin{array}{c}0.004^{* * *} \\
(0.000)\end{array}$ & $\begin{array}{c}0.002 * * * \\
(0.000)\end{array}$ & $\begin{array}{c}0.002 * * * \\
(0.000)\end{array}$ & $\begin{array}{c}0.004 * * * \\
(0.000)\end{array}$ & $\begin{array}{c}0.004 * * * \\
(0.000)\end{array}$ \\
\hline GOVERN & $\begin{array}{c}-0.003^{* * *} \\
(0.000)\end{array}$ & $\begin{array}{c}-0.003^{* * *} \\
(0.000)\end{array}$ & $\begin{array}{c}-0.004 * * * \\
(0.000)\end{array}$ & $\begin{array}{c}-0.005^{* * *} \\
(0.000)\end{array}$ & & & & \\
\hline$\triangle$ PERF_Sens $\times$ GOVERN & & $\begin{array}{c}0.007 * * \\
(0.014)\end{array}$ & & $\begin{array}{c}0.008 * * * \\
(0.004)\end{array}$ & & & & \\
\hline$\triangle$ PRICE_Sens $\times$ GOVERN & & & $\begin{array}{c}-0.000 * * * \\
(0.010)\end{array}$ & $\begin{array}{c}-0.000 * * * \\
(0.002)\end{array}$ & & & & \\
\hline BOARD & & & & & $\begin{array}{c}-0.008 * * * \\
(0.000)\end{array}$ & $\begin{array}{c}-0.008 * * * \\
(0.001)\end{array}$ & $\begin{array}{c}-0.014 * * * \\
(0.000)\end{array}$ & $\begin{array}{c}-0.014 * * * \\
(0.000)\end{array}$ \\
\hline$\triangle$ PERF_Sens $\times$ BOARD & & & & & & $\begin{array}{c}0.024 * * * \\
(0.007)\end{array}$ & & $\begin{array}{c}0.029 * * * \\
(0.001)\end{array}$ \\
\hline$\triangle$ PRICE_Sens $\times$ BOARD & & & & & & & $\begin{array}{c}-0.001 * * \\
(0.014)\end{array}$ & $\begin{array}{c}-0.001 * * * \\
(0.004)\end{array}$ \\
\hline$\Delta$ Size & $\begin{array}{l}-0.000 \\
(0.321)\end{array}$ & $\begin{array}{l}-0.000 \\
(0.287)\end{array}$ & $\begin{array}{l}-0.000 \\
(0.311)\end{array}$ & $\begin{array}{l}-0.000 \\
(0.269)\end{array}$ & $\begin{array}{l}-0.000 \\
(0.304)\end{array}$ & $\begin{array}{l}-0.000 \\
(0.244)\end{array}$ & $\begin{array}{l}-0.000 \\
(0.305)\end{array}$ & $\begin{array}{l}-0.000 \\
(0.234)\end{array}$ \\
\hline$\Delta \mathrm{ICS} i z e$ & $\begin{array}{l}-0.000 \\
(0.116)\end{array}$ & $\begin{array}{l}-0.000^{*} \\
(0.084)\end{array}$ & $\begin{array}{l}-0.000 * \\
(0.082)\end{array}$ & $\begin{array}{c}-0.000^{* *} \\
(0.050)\end{array}$ & $\begin{array}{l}-0.000^{*} \\
(0.098)\end{array}$ & $\begin{array}{c}-0.000 * \\
(0.070)\end{array}$ & $\begin{array}{l}-0.000 * \\
(0.064)\end{array}$ & $\begin{array}{c}-0.000 * * \\
(0.038)\end{array}$ \\
\hline$\Delta$ St. Dev. & $\begin{array}{l}-0.001 \\
(0.492)\end{array}$ & $\begin{array}{l}-0.001 \\
(0.511)\end{array}$ & $\begin{array}{l}-0.001 \\
(0.484)\end{array}$ & $\begin{array}{l}-0.001 \\
(0.504)\end{array}$ & $\begin{array}{l}-0.001 \\
(0.472)\end{array}$ & $\begin{array}{l}-0.001 \\
(0.482)\end{array}$ & $\begin{array}{l}-0.001 \\
(0.451)\end{array}$ & $\begin{array}{l}-0.001 \\
(0.458)\end{array}$ \\
\hline$\Delta$ Inv. Obj. Fee & $\begin{array}{c}0.253 \\
(0.184)\end{array}$ & $\begin{array}{c}0.251 \\
(0.188)\end{array}$ & $\begin{array}{c}0.251 \\
(0.187)\end{array}$ & $\begin{array}{c}0.248 \\
(0.192)\end{array}$ & $\begin{array}{c}0.253 \\
(0.184)\end{array}$ & $\begin{array}{c}0.251 \\
(0.187)\end{array}$ & $\begin{array}{c}0.252 \\
(0.186)\end{array}$ & $\begin{array}{c}0.249 \\
(0.191)\end{array}$ \\
\hline$\Delta$ Inv. Comp. Fee & $\begin{array}{c}0.270^{* * * *} \\
(0.000)\end{array}$ & $\begin{array}{c}0.270 * * * \\
(0.000)\end{array}$ & $\begin{array}{c}0.270 * * * \\
(0.000)\end{array}$ & $\begin{array}{c}0.269 * * * \\
(0.000)\end{array}$ & $\begin{array}{c}0.271 * * * \\
(0.000)\end{array}$ & $\begin{array}{c}0.270 * * * \\
(0.000)\end{array}$ & $\begin{array}{c}0.270 * * * \\
(0.000)\end{array}$ & $\begin{array}{c}0.269 * * * \\
(0.000)\end{array}$ \\
\hline No. of Obs. & 9,623 & 9,623 & 9,623 & 9,623 & 9,623 & 9,623 & 9,623 & 9,623 \\
\hline Adjusted $\mathrm{R}^{2}$ & 0.122 & 0.122 & 0.122 & 0.123 & 0.122 & 0.122 & 0.122 & 0.123 \\
\hline
\end{tabular}


Figure 1

Time variation in price and performance sensitivities

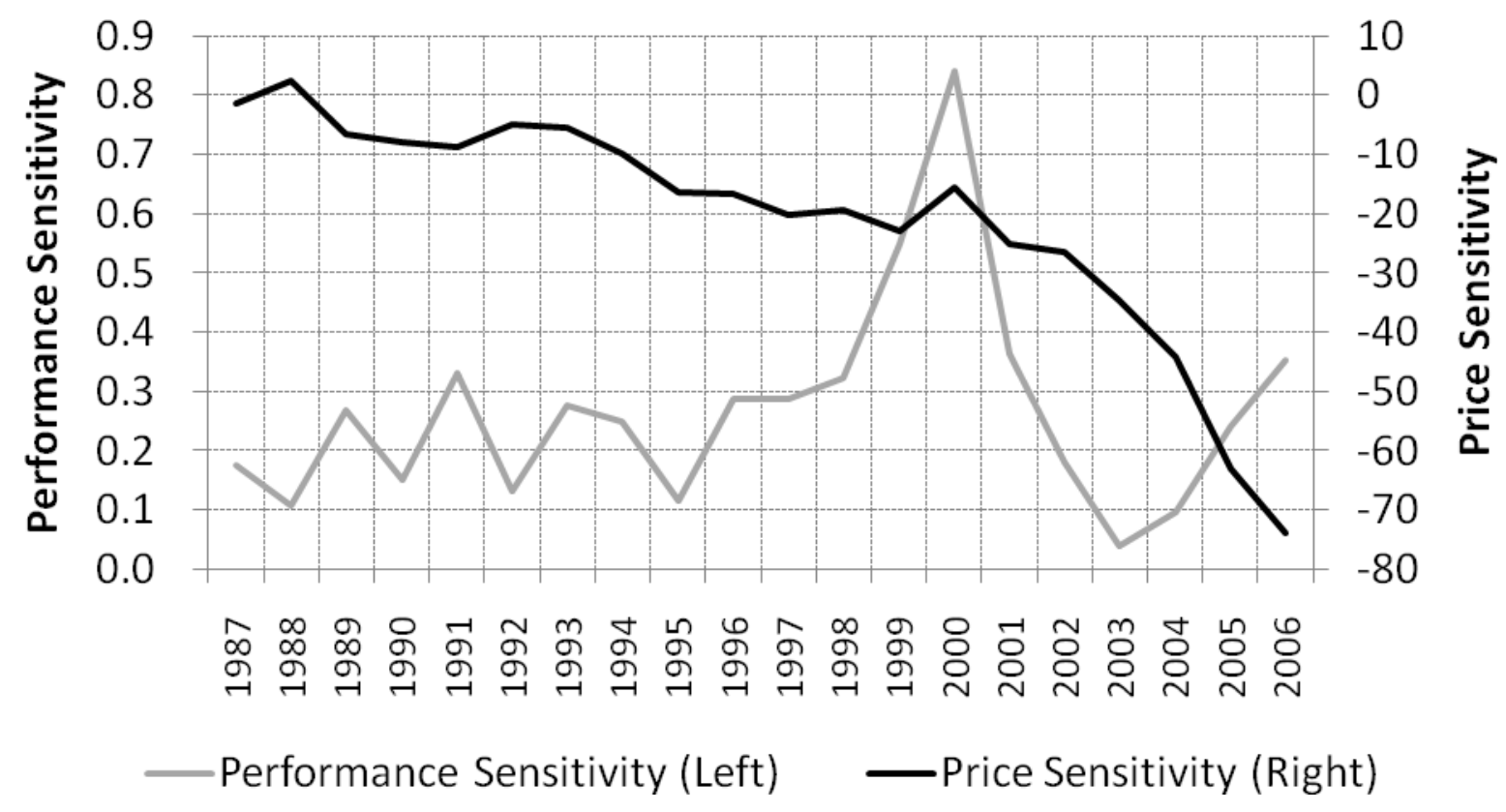

